\title{
A Validated Reverse Phase-Ultra-Performance Liquid Chromatography Method for the Determination of Gemifloxacin Mesylate in Bulk and its Pharmaceutical Preparation
}

\author{
Gemifloksasin Mesilatın Bulk ve Farmasötik Preparatından Tayini için \\ Valide Edilmiş Ters Faz-Ultra-Performans Sıvı Kromatografisi Metodu
}

\author{
(D) Hebatallah A. WAGDY1,2*, (D) Mohamed TAREK1,2, (D) Ahmed AMER2, (D) Menna GAMAL2, (D) Mohey ELMAZAR2,3 \\ 1The British University in Egypt, Faculty of Pharmacy, Department of Pharmaceutical Analytical Chemistry, Cairo, Egypt \\ 2The British University in Egypt, Faculty of Pharmacy, The Center for Drug Research and Development, Cairo, Egypt \\ 3The British University in Egypt, Faculty of Pharmacy, Department of Pharmacology and Toxicology, Cairo, Egypt
}

\begin{abstract}
Objectives: Gemifloxacin Mesylate is a fourth generation fluoroquinolone antibacterial agent. A simple, accurate, and precise reversed phase (RP)ultra performance liquid chromatography (UPLC) method was developed and validated for short time analysis of Gemifloxacin Mesylate in its bulk and pharmaceutical preparation.

Materials and Methods: The optimum separation was achieved at $0.5 \pm 0.03$ min using an Acclaim TM RSLC 120 C18 column $2.2 \mu \mathrm{m}$ ( $2.1 \times 100 \mathrm{~mm}$ ) at $30^{\circ} \mathrm{C}$ by isocratic mobile phase at $\mathrm{pH} 3.0$ composed of acetonitrile:phosphate buffer $(25 \mathrm{mM})$ in a ratio of $75: 25$ ( $\mathrm{v} / \mathrm{v}$ ). The column effluents were monitored at $276 \mathrm{~nm}$ using a photodiode array detector at a flow rate of $0.5 \mathrm{~mL} / \mathrm{min}$. The method was validated according to International Conference on Harmonization guidelines.

Results: The linearity of the calibration curve ranged from $0.5 \mu \mathrm{g} / \mathrm{mL}$ to $10 \mu \mathrm{g} / \mathrm{mL}$ and the square of the regression coefficient $\left(r^{2}\right)$ was 0.9991 . The $\%$ relative standard deviation (RSD) of inter-day precision ranged from $0.081 \%$ to $1.233 \%$, while for intra-day it ranged from $0.364 \%$ to $1.018 \%$. The method was accurate with \% recovery ranging from $93.71 \%$ to $100.29 \%$ and \% RSD ranging from 1.054 to 2.722 . The limit of detection and the limit of quantification were 0.066 and $0.2 \mu \mathrm{g} / \mathrm{mL}$, respectively.

Conclusion: The validated method proved its ability for the assay of Gemifloxacin Mesylate in its bulk and dosage form in a short time (less than 1 $\mathrm{min}$. To the best of our knowledge, this is the first RP-UPLC method for the determination of Gemifloxacin Mesylate.
\end{abstract}

Key words: Gemifloxacin Mesylate, ultra performance liquid chromatography, method validation

öz

Amaç: Gemifloksasin Mesilat dördüncü jenerasyon fluorokinolon antibakteriyel ajandır. Basit, doğru ve hassas bir ters fazlı (RP)-ultra performanslı sıvı kromatografisi (UPLC) yöntemi, Gemifloksasin Mesilatın, bulk ve farmasötik preparatında kısa sürede analizi için geliștirilmiş ve valide edilmiştir. Gereç ve Yöntemler: Optimum ayırma, Acclaim TM RSLC 120 C18, $2.2 \mu \mathrm{m}$ (2.1×100 mm) kolonu kullanılarak, 30 ${ }^{\circ} \mathrm{C}^{\prime}$ de, 75:25 (h/h) asetonitril:fosfat tamponu $(25 \mathrm{mM})$ içeren $\mathrm{pH} 3.0$ izokratik hareketli faz ile $0.5 \pm 0.03 \mathrm{dk}$ 'da elde edildi. Kolon atığı $0.5 \mathrm{~mL} / \mathrm{dk}$ 'lık bir akış hızında fotodiyod detektörü kullanılarak 276 nm'de izlenmiştir. Yöntem Uluslararası Uyumlaştırma Konferansı kılavuzlarına göre valide edildi.

Bulgular: Kalibrasyon eğrisinin doğrusallığı $0.5 \mu \mathrm{g} / \mathrm{mL}$ ile $10 \mu \mathrm{g} / \mathrm{mL}$ arasındadır ve regresyon katsayısının karesi (r2) 0.9991 'dir. Gün içi kesinliğin \% bağıl standart sapması (RSD) \%0.081 ile \%1.233 arasında değişirken, günler arası için \%0.364 ile \%1.018 arasında değișiyordu. Yöntem \%93.71 ile \%100.29 ve \% RSD değeri 1.054 ile 2.722 arasında değișen \% geri kazanım ile doğrudur. Saptama limiti ve tayin limiti sırasıyla 0.066 ve $0.2 \mu \mathrm{g} / \mathrm{mL}$ idi.

Sonuç: Valide edilmiş yöntem, Gemifloksasin Mesilatın bulk ve dozaj formundan tayininde kısa sürede (1 dakikadan az) tayinin olabileceğini kanıtlamıştır. Bildiğimiz kadarıyla, bu, Gemifloksasin Mesilatın belirlenmesi için ilk RP-UPLC yöntemidir.

Anahtar kelimeler: Gemifloksasin Mesilat, ultra performanslı sıvı kromatografisi, metod validasyonu

*Correspondence: E-mail: Hebatallah.wagdy@bue.edu.eg, Phone: +2 26890000 ORCID-ID: orcid.org/0000-0003-1975-7700

Received: 19.10.2017, Accepted: 30.11.2017

๑Turk J Pharm Sci, Published by Galenos Publishing House. 


\section{INTRODUCTION}

Gemifloxacin Mesylate (Figure 1) is a synthetic broad-spectrum antibacterial agent for oral administration. It is a member of the fourth generation fluoroquinolone antibiotics. Its mechanism of action is by inhibition of both topoisomerase IV and DNA gyrase, which are essential for bacterial cell replication. It is characterized by its broad spectrum of activity against both gram-positive and gram-negative bacteria. It is used in the treatment of respiratory tract and urinary tract infections. ${ }^{1-4}$

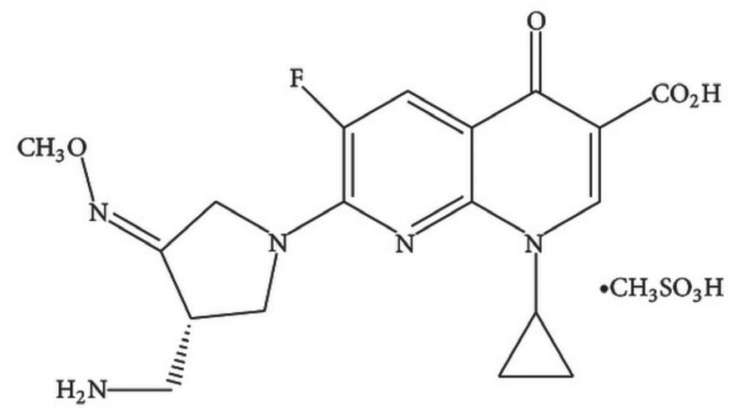

Figure 1. The chemical structure of Gemifloxacin Mesylate

The IUPAC name of Gemifloxacin Mesylate is 7-[(4Z)3-(Aminomethyl)-4-methoxyiminopyrrolidin-1-yl]-1cyclopropyl-6-fluoro-4-oxo-1,8 naphthyridine-3-carboxylic acid, methanesulfonic acid. Its molecular formula is $\mathrm{C}_{18} \mathrm{H}_{20} \mathrm{FN}_{5} \mathrm{O}_{4} \cdot \mathrm{CH}_{4} \mathrm{O}_{3} \mathrm{~S}$; its molecular weight is $485.49 \mathrm{~g} / \mathrm{mol}$.

In the literature, different analytical methods have been reported for its determination, including spectrophotometry, ${ }^{5-7}$ spectrofluorimetry, ${ }^{8-10}$ high performance thin layer chromatography (HPTLC), 11-14 high performance layer chromatography (HPLC)-ultraviolet (UV), ${ }^{15-18}$ and liquid chromatography (LC)-mass spectrometry. ${ }^{19,20}$

Ultra-performance liquid chromatography (UPLC), introduced in 2004, proved to be more efficient than HPLC in many aspects such as resolution, sensitivity, and consuming much smaller amounts of solvents.

The aim of the present research was the rapid and sensitive determination and quantification of Gemifloxacin Mesylate in its bulk and pharmaceutical preparation with lower consumption of solvents using reverse phase (RP)-UPLC-UV in addition to its validation with respect to International Conference on Harmonization (ICH) guidelines. To the best to our knowledge, this is the first RP-UPLC method for the determination of Gemifloxacin Mesylate.

\section{MATERIALS AND METHODS}

\section{Instruments and software}

The UPLC system employed was a Thermo Fisher UHPLC Dionex Ultimate 3000 (Germering, Germany). The pump was an ISO-3100SD, while the autosampler was a WPS 3000 $\mathrm{SL}$, and the column thermostat was a TCC-3000 SD. The detector was a diode array detector (3000 RS) (Germering, Germany). The software utilized for data acquisition was Chromeleon 6.8 (Germering, Germany). pH of the buffer was measured using a pH meter (Jenway pH-meter 3310, Dunmow, Essex, United Kingdom). Milli-Q water was produced in-house from an ultrapure water purification system (Thermo Scientific Barnstead Smart2Pure 3 UV, Hungary). The separation was carried out using an Acclaim ${ }^{\text {TM }}$ RSLC $120 \mathrm{C} 18$ column $2.2 \mu \mathrm{m}$ (2.1×100 mm), Thermo Fisher.

\section{Chemicals and reagents}

Acetonitrile (HPLC grade), monobasic potassium phosphate, and phosphoric acid (high grade) were purchased from Sigma-Aldrich, Germany. Gemifloxacin Mesylate standard was obtained from Sigma Pharmaceutical Company (Cairo, Egypt). Gemifloxacin Mesylate pharmaceutical preparations (Quinabiotic ${ }^{\oplus}$, Utopia) were purchased from the Egyptian market.

\section{Methods}

\section{Mobile phase preparation}

The mobile phase was composed of acetonitrile and $25 \mathrm{mM}$ phosphate buffer ( $\mathrm{pH} 3.00)(75: 25, \mathrm{v} / \mathrm{v})$. The mobile phase was mixed and then degassed using an ultrasonicator.

The phosphate buffer was prepared by mixing monobasic potassium phosphate and phosphoric acid, and then the $\mathrm{pH}$ was measured by the $\mathrm{pH}$ meter and adjusted to 3.00 .

\section{Standard solution preparation and calibration curve plotting}

The standard stock solution was prepared by dissolving $25 \mathrm{mg}$ of Gemifloxacin Mesylate standard in $25 \mathrm{~mL}$ of deionized water, so that the final concentration was $1000 \mu \mathrm{g} / \mathrm{mL}$. After that, serial dilutions $(0.5-10 \mu \mathrm{g} / \mathrm{mL})$ were accomplished to construct the calibration curve.

\section{Sample preparation}

Ten tablets of Quinabiotic ${ }^{\circledR}$ containing $320 \mathrm{mg}$ of Gemifloxacin Mesylate equivalent to $320 \mathrm{mg}$ of Gemifloxacin were accurately weighed and crushed into fine powder. A concentration of $1000 \mu \mathrm{g} / \mathrm{mL}$ was prepared by taking an equivalent amount of $25 \mathrm{mg}$ of Gemifloxacin Mesylate and dissolving it in $25 \mathrm{~mL}$ of deionized water. The solution was sonicated for $15 \mathrm{~min}$ and then filtered using a $0.22-\mu \mathrm{m}$ nylon syringe filter. After that a dilution equivalent to $1 \mu \mathrm{g} / \mathrm{mL}$ was prepared and it was then injected into the UPLC system.

\section{Chromatographic conditions}

The mobile phase was a mixture of acetonitrile and phosphate buffer $(75: 25, \mathrm{v} / \mathrm{v})$ at a flow rate $0.5 \mathrm{~mL} / \mathrm{min}$. The temperature of the column oven was adjusted to $30^{\circ} \mathrm{C}$ and the injection volume of the sample was $10 \mu \mathrm{L}$. The photodiode array (PDA) detector was maintained at a wavelength of $276 \mathrm{~nm}$.

\section{Method validation}

Validation was performed as stated in the $\mathrm{ICH}$ guidelines with reference to the following parameters: linearity, limit of 
quantification and detection, precision (inter- and intra-day), and accuracy. ${ }^{21}$

Linearity is the ability of a method to get a response directly proportional to the sample concentration over a given range. The linearity of the analytical method was determined by preparing 7 serial dilutions ranging from 0.5 to $10 \mu \mathrm{g} / \mathrm{mL}$. Each concentration was injected 3 times into the UPLC. After different peak areas were determined, the average peak area was obtained for each concentration. Hence, concentrations against the average peak area were plotted accordingly in a calibration curve. Using linear regression analysis, the regression equation was determined along with the correlation coefficient. Linearity was evaluated using the square of the regression coefficient $\left(r^{2}\right)$.

For the limit of quantification (LOQ), it is equivalent to the concentration of the analyte in which $S / N$ is equal to 10 , while for the limit of detection (LOD), it is equivalent to the concentration of the analyte in which $\mathrm{S} / \mathrm{N}$ is equal to 3.3 .

Precision measures whether the method is able to generate reproducible results or not. The precision of the method was evaluated using intra-day (repeatability) and inter-day precision (intermediate precision). Intra-day precision was determined by injecting 4 different concentrations into the UPLC; each was injected three times on the same day. The average peak was obtained along with the standard deviation. The precision was evaluated with respect to \% relative standard deviation (RSD). While inter-day precision was obtained by injecting four concentrations into the UPLC system, each concentration was injected 3 times on two consecutive days. The average peak between day one and day two was analyzed to calculate the standard deviation and, accordingly, \% RSD was evaluated.

Accuracy is the closeness of the results obtained from a method to the true reference values. The accuracy of the method was determined by evaluating recovery studies on the pharmaceutical preparation. Three different solutions were prepared; each contained $1 \mu \mathrm{g} / \mathrm{mL}$ pharmaceutical preparation spiked with known concentrations of standard solution of 0.4 $\mu \mathrm{g} / \mathrm{mL}, 0.8 \mu \mathrm{g} / \mathrm{mL}$, and $1.2 \mu \mathrm{g} / \mathrm{mL}$ so that the final concentrations were $1.4 \mu \mathrm{g} / \mathrm{mL}, 1.8 \mu \mathrm{g} / \mathrm{mL} / \mathrm{mL}$, and $2.2 \mu \mathrm{g} / \mathrm{mL}$, respectively. Each sample was injected three times on two consecutive days. Accuracy was evaluated by calculating percentage recovery and, accordingly, \% RSD was determined.

The robustness of the method was assessed by the ability of the method to remain unaffected by small deliberate changes in the following parameters: ${ }^{22}$ wavelength, $\%$ acetonitrile, and $\mathrm{pH}$ of the buffer.

System suitability test

System suitability was tested by injecting a working solution of $1 \mu \mathrm{g} / \mathrm{mL}$ Gemifloxacin Mesylate under the optimum condition.

\section{RESULTS AND DISCUSSION}

\section{Method development}

In order to achieve the optimum condition, the analytical conditions, including temperature, mobile phase composition, wavelength, and flow rate, were optimized.
At the beginning, methanol was investigated as an organic solvent, instead of acetonitrile. Better peak shape and shorter retention time were achieved using acetonitrile.

Both the buffer strength and $\mathrm{pH}$ were also studied. Although a higher concentration of buffer gave a shorter retention time and better peak shape, it led to an increase in pump pressure; accordingly, $25 \mathrm{mM}$ was selected as the optimum buffer strength. For $\mathrm{pH}$, a value greater than 3.00 showed a broader peak and lower $\mathrm{pH}$ did not improve the peak shape. As a consequence, $\mathrm{pH} 3.00$ was chosen as the optimum buffer $\mathrm{pH}$. This could be explained by the fact that at $\mathrm{pH} 3.00$ it was below the pKa of Gemifloxacin Mesylate ( $\mathrm{pKa}_{1}=5.53, \mathrm{pKa}_{2}=9.53$ ).

While for the temperature, reaching $\mathrm{T} 30^{\circ} \mathrm{C}$ was enough to enhance the peak shape, higher temperature did not have a significant effect on the peak. For the flow rate, $0.5 \mathrm{~mL} / \mathrm{min}$ was optimum to achieve a short analysis time without increasing the pump pressure.

The optimum wavelength for detecting Gemifloxacin Mesylate was $276 \mathrm{~nm}$ using the PDA detector as shown in the spectrum (Figure 2). The flow rate was set at $0.5 \mathrm{~mL} / \mathrm{min}$. The optimum temperature for analysis was $30^{\circ} \mathrm{C}$ and the $\mathrm{pH}$ for the phosphate buffer was 3.0. The mobile phase composition was acetonitrile: $25 \mathrm{mM}$ phosphate buffer, $\mathrm{pH} 3.00$ (75:25 v/v). Under this condition, the peak for Gemifloxacin Mesylate appeared at $t R$ $0.5 \pm 0.03 \mathrm{~min}$ (Figure 3 ). To the best to our knowledge, this is the first UPLC-PDA method for the analysis of Gemifloxacin Mesylate reported in the literature. Accordingly, when compared to other HPLC-UV methods reported in the literature, it provided shorter analysis time and less consumption of solvents.

Next, the analytical method developed was evaluated and validated as per $\mathrm{ICH}$ guidelines.

\section{Validation of the developed method}

\section{Linearity}

The graphical representation calibration curve shows that the linearity ranged from 0.5 to $10 \mu \mathrm{g} / \mathrm{mL}$. Using linear regression analysis, the slope, the intercept, and the regression coefficient

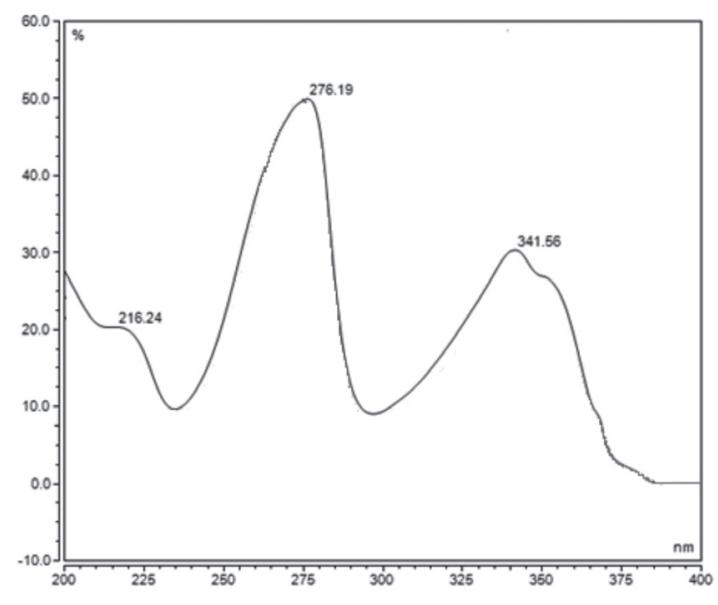

Figure 2. Ultraviolet spectrum of Gemifloxacin Mesylate 


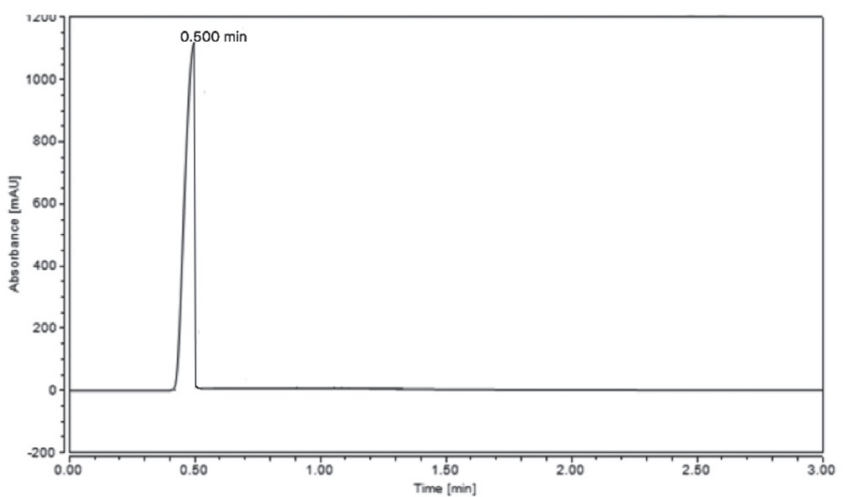

Figure 3. Chromatograms of $1 \mu \mathrm{g} / \mathrm{mL}$ Gemifloxacin Mesylate under the optimum condition, i.e., acetonitrile: $25 \mathrm{mM}$ phosphate buffer, $\mathrm{pH} 3.00$ $(75: 25 ; \mathrm{v} / \mathrm{v})$, at a flow rate $0.5 \mathrm{~mL} / \mathrm{min}$ and $\mathrm{T} 30^{\circ} \mathrm{C}$

were determined from the regression equation $y=396.69 x-$ 6.8416. The regression coefficient $\left[R^{2}\right]$ was equal to 0.9991 . The slope was 396.69 and the intercept was 6.8416.

The LOD was $0.066 \mu \mathrm{g} / \mathrm{mL}$, while the LOQ was $0.2 \mu \mathrm{g} / \mathrm{mL}$.

\section{Precision}

For the inter-day precision \% RSD was determined and ranged from $0.0807 \%$ to $1.2326 \%$, while for intra-day precision $\%$ RSD ranged from $0.1562 \%$ to $1.0176 \%$.

The results of both inter- and intra-day precision are shown in Table 1.

\section{Accuracy}

Accuracy of the method was evaluated. \% Recovery ranged from $93.71 \%$ to $100.29 \%$ while $\%$ RSD ranged from 1.054 to 2.721 as shown in Table 2.

\section{Table 1. Inter-day and intra-day precision of Gemifloxacin Mesylate}

\begin{tabular}{lllll}
\multirow{2}{*}{$\begin{array}{l}\text { Concentration } \\
(\mu \mathrm{g} / \mathrm{mL})\end{array}$} & \multicolumn{2}{l}{ Inter-day precision } & \multicolumn{2}{l}{ Intra-day precision } \\
\cline { 2 - 5 } & Peak area* & $\%$ RSD & Peak area* & \% RSD \\
\hline 1 & 76.458 & 1.233 & 75.791 & 0.156 \\
\hline 2 & 145.734 & 0.653 & 145.061 & 1.018 \\
\hline 4 & 230.634 & 0.368 & 230.035 & 0.364 \\
\hline 8 & 306.400 & 0.081 & 306.575 & 0.653 \\
\hline
\end{tabular}

RSD: Relative standard deviation, *Average of 3 times

\section{Table 2. Accuracy of Gemifloxacin Mesylate}

\begin{tabular}{lllll}
$\begin{array}{l}\text { Theoretical } \\
\text { concentration } \\
(\mu \mathrm{g} / \mathrm{mL})\end{array}$ & $\begin{array}{l}\text { Actual } \\
\text { concentration* } \\
(\mu \mathrm{g} / \mathrm{mL})\end{array}$ & \% RSD & \% Recovery* & \% RSD \\
\hline 1.4 & 1.374 & 1.197 & 98.19 & 2.722 \\
\hline 1.8 & 1.687 & 0.632 & 93.71 & 1.054 \\
\hline 2.2 & 2.206 & 1.217 & 100.29 & 1.723 \\
\hline
\end{tabular}

RSD: Relative standard deviation, *Average of 3 repetitions

\section{Robustness}

To evaluate the robustness of the method, minor changes were made to the parameters intentionally. Hence, the \% RSD was calculated and the results were as follows: wavelength $276 \pm 3$ $\mathrm{nm}$ with \% RSD $1.73 \%$, the $\%$ acetonitrile $75 \pm 1 \%$ with $\%$ RSD $2.35 \%$, and $\mathrm{pH}$ of the buffer $3.00 \pm 0.5$ with \% RSD $2.90 \%$.

\section{System suitability test}

System suitability was tested to demonstrate the adequacy of the analysis system. In order to accomplish that, different parameters were verified. The column efficiency, which can be evaluated by the plate number, the asymmetric factor to evaluate the peak symmetry, and the reproducibility of the system were assessed by the \% RSD of both the peak area and the retention time. The data are presented in Table 3.

\begin{tabular}{|c|c|}
\hline Parameters & Gemifloxacin Mesylate \\
\hline Number of theoretical plates $(\mathrm{N})$ & 3300 \\
\hline Asymmetric factor $\left(\mathrm{A}_{\mathrm{s}}\right)$ & 1.05 \\
\hline Capacity factor & 5.25 \\
\hline$\%$ RSD (retention time)* & 0.35 \\
\hline$\%$ RSD (peak area)* & 0.634 \\
\hline
\end{tabular}

UPLC: Ultra-performance liquid chromatography, RSD: Relative standard deviation, *Average of 4 repetitions

\section{Application on pharmaceutical preparation}

To determine the suitability of the method for the determination of Gemifloxacin Mesylate in its pharmaceutical preparations, Quinabiotic $^{\circledR} 320 \mathrm{mg}$ was purchased from the local market. Next, 10 tablets were weighed and crushed. Hence an equivalent amount of $25 \mathrm{mg}$ was dissolved in $25 \mathrm{~mL}$ of deionized water, followed by sonication and filtration. Then the filtrate was diluted with deionized water to have a concentration equivalent to $1 \mu \mathrm{g} / \mathrm{mL}$. As presented in Figure 4, the tR of Gemifloxacin Mesylate was $0.500 \mathrm{~min}$ and tablet excipients did not interfere with the analysis. The \% recovery was 99,496 with \% RSD

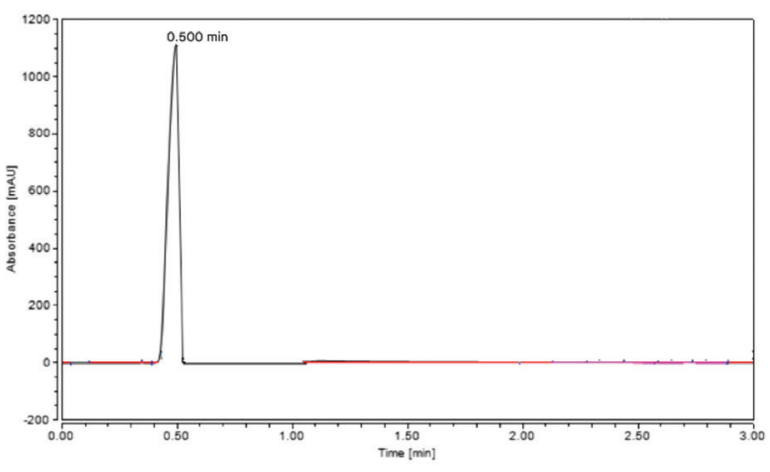

Figure 4. Chromatograms of $1 \mu \mathrm{g} / \mathrm{mL}$ Quinabiotic $®$ under the optimum condition, i.e., acetonitrile: $25 \mathrm{mM}$ phosphate buffer, pH 3.00 (75:25; v/v), at a flow rate $0.5 \mathrm{~mL} / \mathrm{min}$ and $\mathrm{T} 30^{\circ} \mathrm{C}$ 
1431. Accordingly, the method proved its ability to determine Gemifloxacin Mesylate in its pharmaceutical preparations.

\section{Statistical analysis}

To ensure the applicability of the newly suggested method, it was compared to a published reference method. It was investigated whether there are any significant differences between the two methods and to what extent this difference can affect the applicability of the new method rather than an already used one.

Comparing the obtained $\mathrm{F}$ - and $\mathrm{t}$-values with the tabulated ones, it is clear that the obtained values were lower than the theoretical tabulated values, i.e., the methods suggested do not exhibit significant differences in comparison to those of the published methods, which reflects the accuracy and precision of the suggested UPLC method. The results are shown in Table 4.

Table 4. Statistical comparison between the proposed method and reference methods

Proposed method Reference method

\begin{tabular}{lll}
\hline Pure solution & & \\
\hline Mean \pm SD & $100.06 \pm 0.76$ & $99.38 \pm 0.51^{23}$ \\
\hline $\mathrm{n}$ & 7 & 6 \\
\hline Student's t-test (tabulated) & $1.91(2.18)$ & \\
\hline F test (tabulated) & $2.24(4.95)$ & \\
\hline Probability & $<0.05$ & \\
\hline Quinabiotic & \\
\hline Mean \pm SD & \\
\hline $\mathrm{n}$ & $97.40 \pm 1.83$ & $98.48 \pm 1.82^{11}$ \\
\hline Student's t-test (tabulated) & $0.81(2.37)$ & 5 \\
\hline F test (tabulated) & $1.01(6.94)$ \\
\hline Probability & $<0.05$ \\
\hline
\end{tabular}

SD: Standard deviation

\section{CONCLUSIONS}

The newly developed RP-UPLC method for the short time analysis of Gemifloxacin Mesylate in its bulk and pharmaceutical preparation was rapid, simple, accurate, and precise. The method was validated as per ICH guidelines for linearity, accuracy, and precision. Linearity was determined at an acceptable range from 0.5 to $10 \mu \mathrm{g} / \mathrm{mL}$. Finally, the method was accepted for the analytical evaluation of the drug in its pharmaceutical preparations with respect to the satisfactory results obtained and it showed a lower retention time in comparison to other HPLC methods reported in the literature.

Conflict of Interest: No conflict of interest was declared by the authors.

\section{REFERENCES}

1. Oh JI, Paek KS, Ahn MJ, Kim MY, Hong CY, Kim IC, Kwak JH. In vitro and in vivo evaluations of LB20304, a new fluoronaphthyridone. Antimicrob Agents Chemother. 1996;40:1564-1568.

2. Cormican MG, Jones RN. Antimicrobial activity and spectrum of LB20304, a novel fluoronaphthyridone. Antimicrob Agents Chemother. 1997;41:204-211.

3. Hohl AF, Frei R, Pünter V, von Graevenitz A, Knapp C, Washington $\mathrm{J}$, Johnson D, Jones RN. International multicenter investigation of LB20304, a new fluoronaphthyridone. Clin microbiol infec. 1998;4:280284.

4. Lomaestro BM. Gemifloxacin: A broad-spectrum oral quinolone for treatment of respiratory and urinary tract infections. Formulary. 2000;35:961-968.

5. Tirupathi B, Venkateshwarlu G. Spectrophotometric determination of drugs using chloramine-T and rhodamine-B dye. Int J Pharma Bio Sci. 2015;6:218-226.

6. Paim CS, Führ F, Miron DS, Steppe M, Schapoval EE. Highly Selective Colorimetric Method to Determine Gemifloxacin Mesylate in the Presence of a Synthetic Impurity. J AOAC Inter. 2014;97:94-98.

7. Krishna MV, Sankar DG. Spectrophotometric determination of gemifloxacin mesylate in pharmaceutical formulations through ion-pair complex formation. J Chem. 2008;5:515-520.

8. Al-Tamimi S, Al-Mohaimeed AM, Alarfaj N, Aly F. Stability-indicating Spectrofluorimetric methods for determination of Gemifloxacin Mesylate in pharmaceutical dosage forms. J Ind Chem Soc. 2014;91:1247-1254.

9. Moussa BA, Mahrouse MA, Hassan MA, Fawzy MG. Spectrofluorimetric determination of gemifloxacin mesylate and linezolid in pharmaceutical formulations: application of quinone-based fluorophores and enhanced native fluorescence. Acta Pharm. 2014;64:15-28.

10. Kepekci Tekkeli SE, Önal A. Spectrofluorimetric methods for the determination of gemifloxacin in tablets and spiked plasma samples. J fluoresc. 2011;21:1001-1007.

11. Mahmoud AM, Atia NN, El-Shabouri SR, El-Koussi WM. Development and Validation of Stability Indicating HPTLC Assay for Determination of Gemifloxacin Mesylate in Dosage Forms. Am J Anal Chem. 2015;6:85-97.

12. El-Koussi WM, Atia NN, Mahmoud AM, El-Shabouri SR. HPTLC method for direct determination of gemifloxacin mesylate in human plasma. J Chromatogr B Analyt Technol Biomed Life Sci. 2014;967:98-101.

13. Raja T, Atmakuri LO. Development and validation of HPTLC method for the simultaneous estimation of gemifloxacin mesylate and ambroxol hydrochloride in bulk and tablet dosage form. Anal Chemi Lett. 2012;2:152-158.

14. Rote AR, Pingle SP. Reverse phase-HPLC and HPTLC methods for determination of gemifloxacin mesylate in human plasma. J Chromatogr B Analyt Technol Biomed Life Sci 2009;877:3719-3723.

15. Baig MS, Dehghan MHG. Development and validation of in-vitro dissolution studies of Gemifloxacin Mesylate and Ambroxol Hydrochloride from its combined sustain release tablet dosage form with its combined sustain release tablet dosage form with respect to accelerated aging conditions by HPLC assay methods. W J Pharm Pharm Sci. 2015;4:1965-1981.

16. Gumustas M, Ozkan SA. Simple, sensitive and reliable LC-DAD method of gemifloxacin determination in pharmaceutical dosage forms. Turk $J$ Pharm Sci. 2012;9:161-170.

17. Sultana N, Arayne MS, Shamim S, Akhtar M, Gul S. Validated method for the determination of Gemifloxacin in bulk, pharmaceutical formulations 
and human serum by RP-HPLC: in vitro applications. J Braz Chem Soci. 2011;22:987-992.

18. Mohammad Y, Kumar BP, Hussain A, Harish. Development and validation of RP-HPLC method for the estimation of gemifloxacin mesylate in bulk and pharmaceutical dosage forms. J Chem. 2010;7:1621-1627.

19. Tammam MH. Photostability studies on gemifloxacin and lomefloxacin in bulk powder and dosage forms. Eur J Chem. 2014;5:73-80.

20. Roy B, Das A, Bhaumik U, Sarkar AK, Bose A, Mukharjee J, Chakrabarty US, Das AK, Pal TK. Determination of gemifloxacin in different tissues of rat after oral dosing of gemifloxacin mesylate by LC-MS/MS and its application in drug tissue distribution study. J Pharm Biomed Anal. 2010;52:216-226.
21. ICH Guideline Q2a (R1) Validation of analytical proce-dures: text and methodology. 2015: https://www.fda.gov/Drugs/ GuidanceComplianceRegulatoryInformation/Guidances/ucm 265700. htm

22. Wagdy HA, Aboul-Enein HY. Analysis of Sitagliptin On Halogenated Reversed Phase Columns: A Comparative Study. J Pharm Anal. 2016;5:915.

23. Al Mohaimeed AM, Al-Tamimi SA, Alarfaj NA, Aly FA. New coated wire sensors for potentiometric determination of gemifloxacin in pure form, pharmaceutical formulations and biological fluids. Int J Electrochem Sci. 2012;7:12518-12530. 